\title{
Teaching Speaking through SCAS Model to Arouse Students' Patriotism
}

\author{
Hayati Syafri and Sendu Ardila \\ IAIN Bukittinggi \\ Bukittinggi, Indonesia \\ hayati.syafri@gmail.com and sendu.ardila@yahoo.com
}

\begin{abstract}
Nowadays,many latent perils such as communism, radical ideology, and separatist movement can threaten the unity of Indonesia. Bhakti (2016) argues that the unity of Indonesia is in a disarray condition. Futhermore, other experts say that this condition happens because of the patriotism in the student's life has started to vanish as the influence of globalization that detract their identities and love to their country. Besides, there are many students who idolized the figures out of their country. Sadly, they are not attentive with their local prominent figures who have amazing character, good morality and much accomplishment. Due to the degragation and scraping of patriotism of the students, the writers developed some materials for thestudents in IAIN Bukittinggi by using the PIE (Planning, Implementing and Evaluating) to insert the biography of the prominent figures in the speaking material. It is supported by Socio-Cultural Affective Strategies (SCAS) model which considering the social, affective, and culture with multi-dimensional of speaking material by the used of video call with native speaker that can influence patriotism of the students. Briefly, this developing material effectively help the students to counteract them from indeterminate as the effect of globalization that furnish the insight of the students about interculturality.
\end{abstract}

Keywords: patriotism, speaking materials development, SCAS-Model

\section{INTRODUCTION}

Patriotism is actto love and sense for the nation, the act is supported with the action to defense the motherland that can distroy the unity of the nation.Suprapto et al (2007) said that the patriotism is someone's spirit of love for the motherland and the attitute of willing to sacrifice everything to former glory and prosperity of the homeland. Based on the definition,researchers can conclude that the patriotism is the someone's soul and the spirit of love for his motherland and the act to complement the existance of nasionalism. Indonesia is the one of the multi-cultural country. The people in the country need to love their nation, have to know about their culture and they must to love their heroes who had keep fighting and resist the allies from their country. But the problem in indonesia is the patriotism in the lots of the students's life has started to be scraping. That problem happens because of the the effect of the globalization, the students prefer to adore and admire the public figures of the out of their country, such as the artist, singers, dancer, etc. they try to imitate and reverse their idol's lifestyle without know if their idols have not the good manners. Sadly, the students do not know that in their local they have the prominant figures who have good morality, have amazing characters and have many accomplishments.

Base on the problem above, the researchers try to find out the effective way to counteract the influence of the globalization in the students' life within arousing students' patriotism. Education is the biggest field to arouse the patriotisme in the students' life, because of that the material that use in the classroom must contain the local culture. The students must to be exposed abouttheir local prominant figures in the speaking materials. The material that used to teach the speaking need to develop with the new technical, the material must to be inserted with the local cultural.

The speaking material is developed by inserting the students' culture, the english students need to be exposed with their local culture, they have can compare their local culture with the others. It is the obligation for the speaking lecturers, the lecturers should teach the culture when they teach the language in the classroom. As Englebert (2004) said that when the teachers teach a foreign language is also they have to teach a foreign culture too, it is important to be sensitive thing to the fact the students, colleges, administrators, and if we live in a board we do not need to share all of our paradigma's culture to our neighbour. The speaking material must to be integrating with the local culture that hope can arouse students character building about their own culture by Speaking material.

It is not easy to find the materials in the speaking class. The lecturers can design their teaching materials as their wants. It should involve by inserting the cultural of local wisdom and the main goals of the teaching materials should be convey in the right intention. As Tomlinson ( 1998) said that second language teaching materials can be created by the teachers and the students, not only created by the researchers. In other words, the materials that have developed should be understood by the teachers or the students. Nunan (1989) state that communication should not be seen as aproduct rather than be seen as a set of products, it is also supported with the perception of Breen (1984) that is called with the " process syllabus". Based on the syllabus, when the material that script by researchers they appear the materials as plan for predesigned, it is not the final 
production yet but the users (teachers and students) can be open it as the reinterpretation of that plan. The plan of both designs have the plan to join each other in right to shape users' attitutes, knowledge, and perception. Bao Dat in Tomlinson (2003) state that the through interaction such as predesigns sketch can best modified to appropriate materials become the implementation of powerful tool for discovered and created in the speaking materials.

The insertingmaterial about prominant figures in speaking material by using SCAS Model about heroe's live biography was assessingin IAIN Bukittinggi by 3 participants from English Education IAIN Bukittinggi year 2016. The result of assessing the modul is included in good criteria with the percentage total score is $93 \%$. After assessed the module, the researchers want to apply the modul in the speaking class in IAIN Bukittinggi. The researchers believe that the implementation of the speaking material that the insertion of the local culture can affectively to arousing students patriotism.

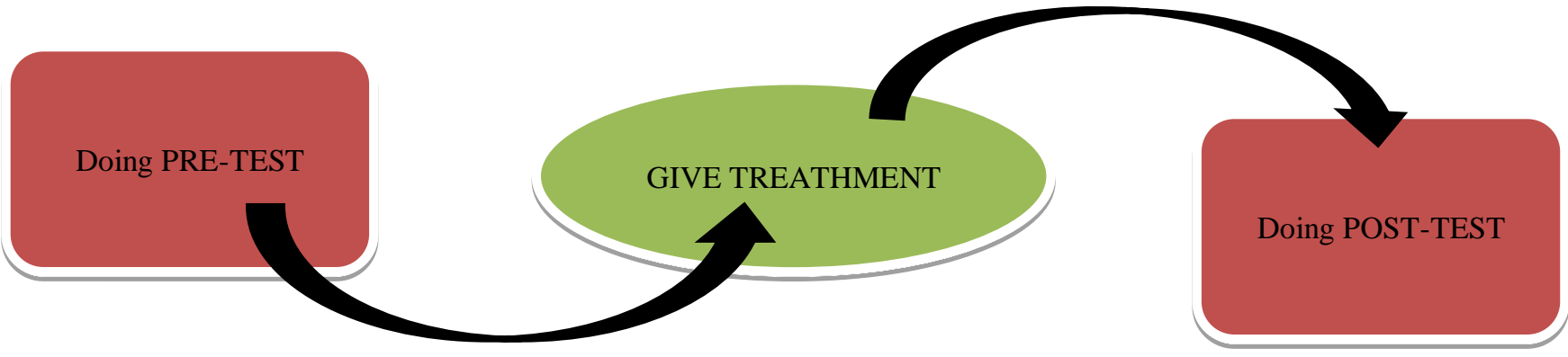

Fig. 1 The sceme of the experiment research

\section{METHOD}

The research design used in this research is Research and Develoment (R and D) research, this research is supported by using PIE model. The objects in this research arethe 30 students from second grade in 2015/2016 academic year of English Department at the State of Islamic Religious Institute (IAIN) Bukittinggi. PIE model is the model that focus on the classroom oriented, this model is appliedby using ICT ( Information, and Communication Technology) and has three stages modelling, that are: Planning,Implementation, and Evaluation.

The sceme of applying PIE model in the classroom, see bellow:

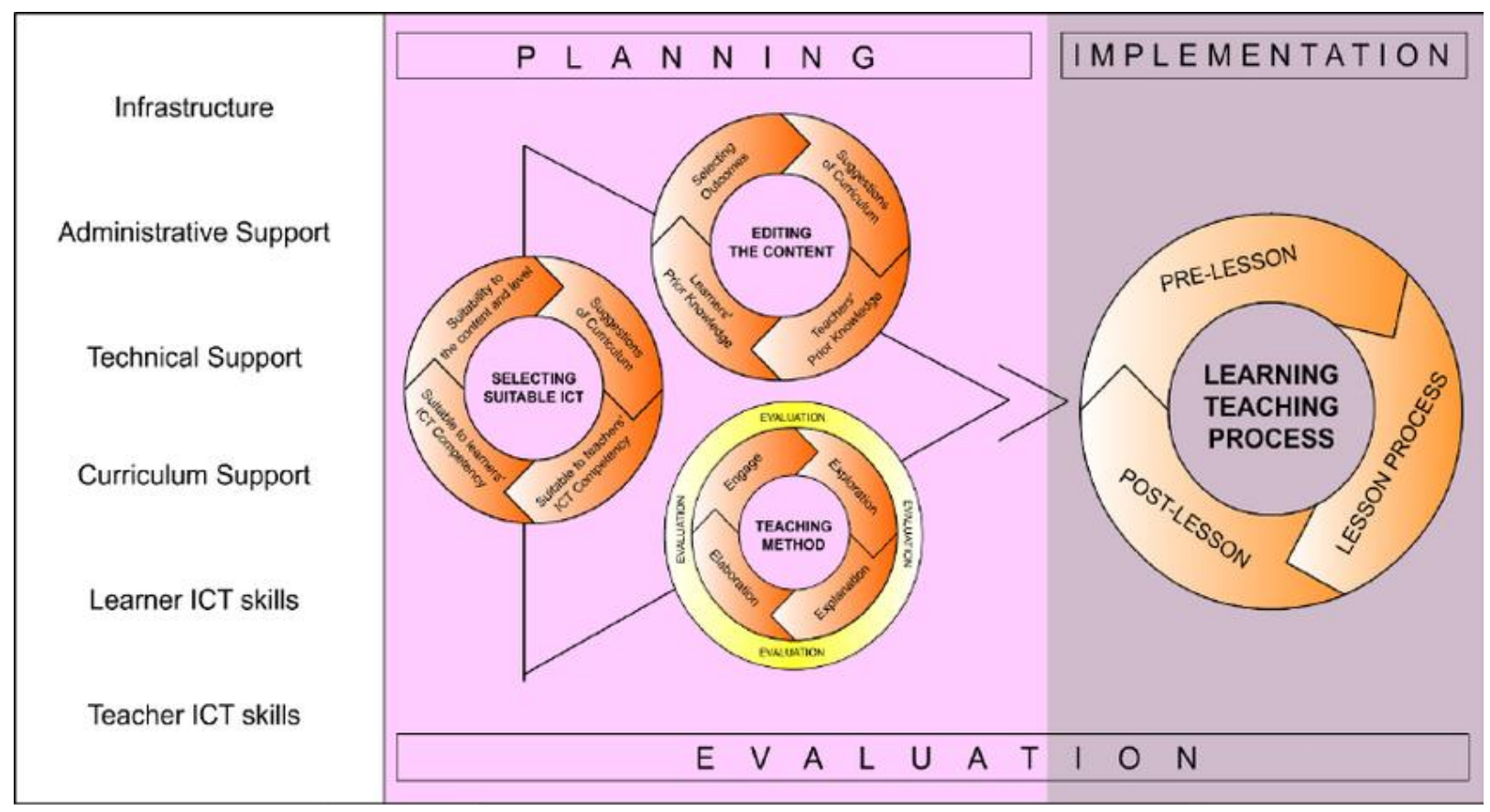

Fig. 2 Planning-Implementation-Evaluation (PIE) model for ICT Integration (Y1ldı, 2013) 
Planning stage is a theoritical process, in this stage the researchers ask the problem to the speaking lecturer and english students in IAIN Bukittinggi about their knowledge of Indonesian prominant figures, from that interview the researchers got that many students did not know about their local prominant figures. After that the researchers asked to the speaking lecturer what she needs and what can do to arouse students patriotism. In the next planning, after asked to the lecturer about what she need to insert in the material, the researchers create material and show the goals of the logic model. and then, the researchers create the strategies and activities budgetting by using SCAS model and supported with ICT. Before the material implement to the classroom, the researchers ask to the expert to valid the material, after researchers get validity and reliability assessing from the expert, and the researchers ask to the participants to fill out the score for the module, the score is $93 \%$ and included in good category, after that the material is ready to be implementing for one meeting in the classroom.

Before doing the treathment, the reserachers do pre-test in the speaking classroom to see how far their comprehend about the material and to see their patriotism. The researchers created the objectives of the study before apply the module in the classroom. The module about heroe's live biography has lots the objectives of the study, the objectives of study inform that what are the the objective of study that can students get after end this lesson. In this module, there are 3 points that students must reach after done this lesson. Here is the data will shows in the coloum bellow:

Table 1. Objective of the study

\begin{tabular}{|l|l|}
\hline \multicolumn{1}{|c|}{ No } & $\begin{array}{l}\text { Tbjectives of The Study } \\
\text { Biography in Education }\end{array}$ \\
\hline $\mathbf{1}$ & $\begin{array}{l}\text { The students are able to describe about theduration of states and event relate to heroes' biography in } \\
\text { education from the target cultures }\end{array}$ \\
\hline 3 & \begin{tabular}{l} 
The students are able to compare about local and target of heroes' live biography in education \\
\hline
\end{tabular} \\
\hline
\end{tabular}

After did the planning, the second stage is Implement process, in the the implementation of organized context during learning and teaching process in three different process: first, before lesson; in this phase the lecturers inform the preparations for the lesson and what students need to do before the class.Second, Lesson process; in this periode,the classroom in complience the teaching method. Activities that will be presented to students should prepared according to ICT that was selected by teaching method. Third, After Lesson; this formation stage isfor homework, the meeting can be online/offline discussion environments for students to continue the relationship between students and content after the lesson, this periode happens after face to face lesson until the next lesson, but the students must be conducted so that they will not disassociate themselves from the lesson. That is mean that the treathment that researchers do is to build up students' learning experience and hope they can aplicate the media in the classroom.

The researchers created 12 processes in the speaking materials that can be applying to teach heroes' live biography by using SCAS Model in the speaking classroom. the 12 processes will show in the table bellow:

Table 2. the 12 processes to teach speaking by using SCAS Model

\begin{tabular}{|c|r|}
\hline No & The Processes to teach the heroes' live biography by using SCAS Model in the classroom \\
\hline $\mathbf{1}$ & Students answer some questions from lecturer about the local prominant figures \\
\hline $\mathbf{2}$ & Students motivate themselves through Ayah that related to the material from Alquran \\
\hline $\mathbf{3}$ & Students discuss with the lecturer about the insert meaning in the funny pictures and related to the topic \\
\hline $\mathbf{4}$ & Students watch a short film or video about the topic in local culture and discuss it \\
\hline $\mathbf{5}$ & Students listen Lecturer's explainationabout some expressions related to speaking's material \\
\hline $\mathbf{6}$ & Students get some situations from the lecturer, create a short dialog about the situtation and practice it \\
\hline
\end{tabular}


Table 2. Cont

\begin{tabular}{|c|c|}
\hline 7 & $\begin{array}{r}\text { Students are divides by the lecturer become some groups and each group discuss different text } \\
\text { about the topic in target cultures }\end{array}$ \\
\hline $\mathbf{8}$ & $\begin{array}{r}\text { Students present the result of the discussion in front of the class } \\
\text { Students have task in group to do intercultural communication for comparing their local and target } \\
\text { cultures about the topic by using technology (Video Call) }\end{array}$ \\
\hline $\mathbf{1 0}$ & $\begin{array}{r}\text { Students from each group present and share their experiences in speaking with native through } \\
\text { technology by comparing their own culture with the target culture }\end{array}$ \\
\hline $\mathbf{1 2}$ & $\begin{array}{r}\text { The students solve the case that is given by the lecturer } \\
\text { Students discuss how to filter the existent culture based on the case and conclude it }\end{array}$ \\
\hline
\end{tabular}

After did the implementation stage, the last stage is called evaluation, the evaluation process has differences with both of the planning and implementation stage. Evaluation is conducted interactively and holistically in both planning and implementation processes, this evaluation stage is the accepted as indispensable for every process. All decisions such as how the process is run and where intervention and correction require can be made with evaluation process. Data from evaluations should be used to improve the next stage. the process evaluation (PIE) methodology aims to address the limitation, in the evaluation researchers do the evaluation that evaluate students learning and see if the effectiveness of the lesson. And the next stage is the researchers do the evaluation process to measure whether the development of material had effective to arousing students patriotism. After do all of the stages in this research, the researchers do post-test to see how far the modul gives improvement in speaking class.

\section{FINDING AND DISCUSSION}

This research design is one-group pre-test post-test design. Operational field testing was done to students of IAIN Bukittinggi with 30 participants in the second semester of class D. The data was analyzed with quantitative way to know the effectiveness of this model to improve students' patriotism. Before doing the study, researchers conducted a pretest to determine the students' abilities. After applied SCAS model to English students of IAIN Bukittinggi, the researchers did the post-test. Following the assessment of examiner:

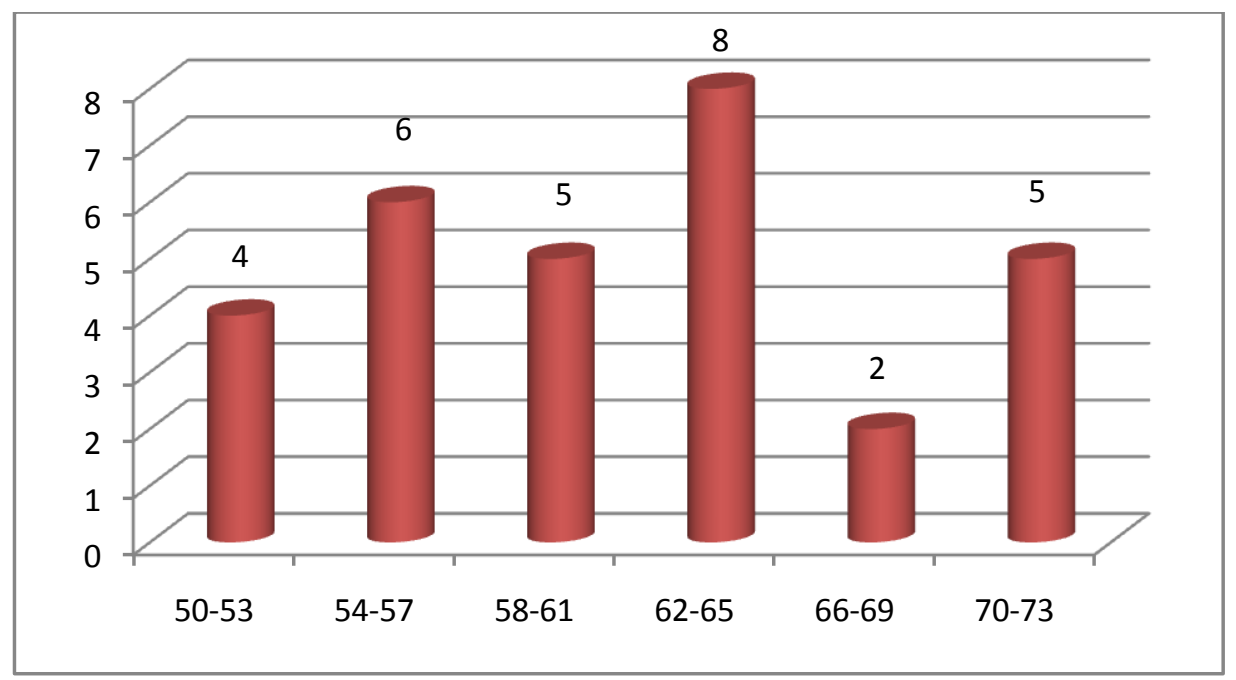

Fig 3. Image1. Pretest Polygon Class Interval Frequency Distribution

Graph polygon above is interval class for the pretest. graph polygon describes highest to the lowest grade from the interval class as follows: from 30 students, most frequencies are at intervals of 62-65 as many as 8 students or $26.7 \%$ of the students. At the next class rank interval is 54-57 as many as 6 students or $20 \%$ of the students. Then, the next class interval 58-61 
and 70-73 as each class interval as many as 5 people or $16.7 \%$ of the students. The lowest class interval is $66-69$ as 2 students or $6.7 \%$ of the students.

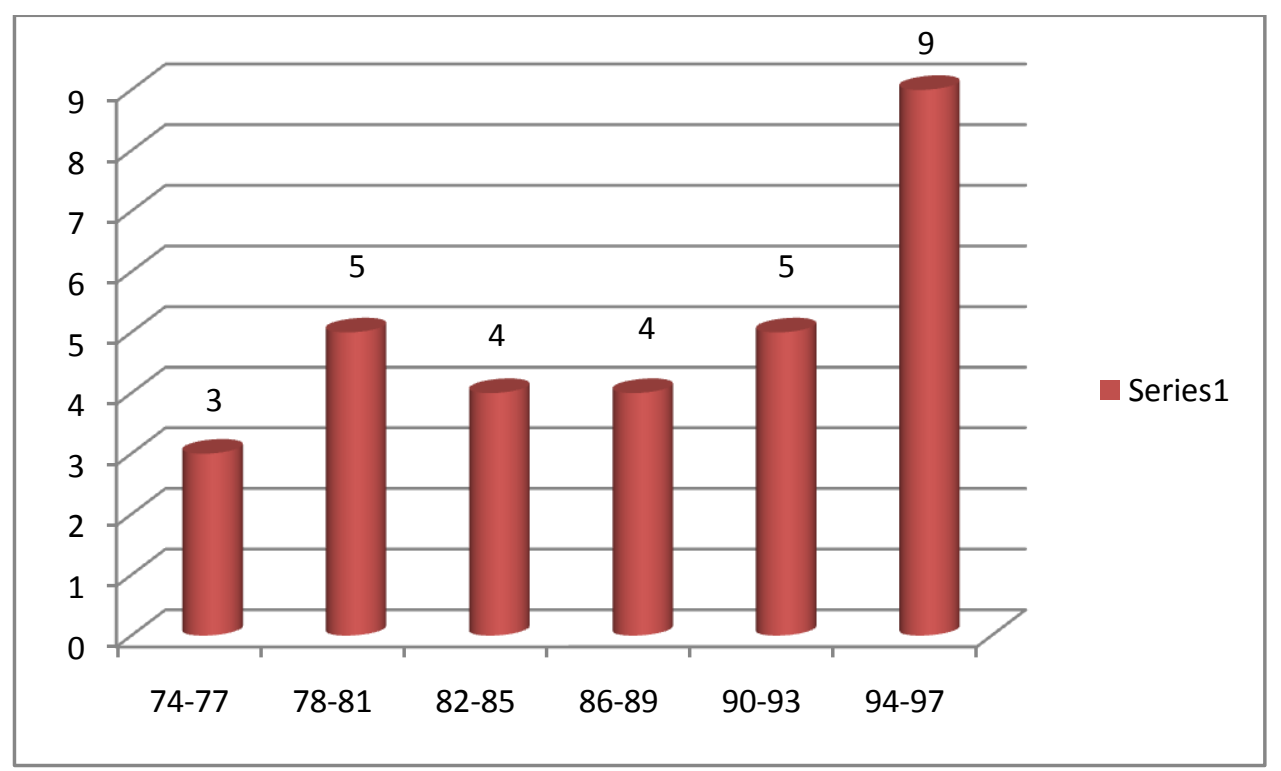

Fig. 4 Posttest Polygon Class Interval Frequency Distribution

Graph polygon of post-test above is interval class for the pretest. graph polygon describes highest to the lowest grade from the interval class as follows: from 30 students, most frequencies are at intervals of 94-97 as many as 9 students or $30 \%$ of the students. At the next class rank intervals are 78-81 and 90-93 as each class interval as many as 5 students or $16.7 \%$ of the students. Then, the next class intervals are $82-85$ and $86-89$ as each class interval as many as 4 people or $13.3 \%$ of the students. The lowest class interval is $74-77$ as 3 students or $6.7 \%$ of the students.

Table 3. The Improvement of Test Result Post-Treatment

\begin{tabular}{|c|c|c|c|c|c|}
\hline No & Indicators & Pre-test score & Post-test score & \multicolumn{2}{|c|}{ Improvement } \\
\cline { 3 - 6 } & & & & score & \% \\
\hline 1 & Grammar & 50 & 74 & 24 & $48 \%$ \\
\hline 2 & Vocabulary & 63 & 89 & 23 & $51.2 \%$ \\
\hline 3 & Comprehension & 58 & 91 & 33 & $39 \%$ \\
\hline 4 & Fluency & 63 & 88 & 25 & $36.2 \%$ \\
\hline 5 & pronunciation & 69 & 94 & 25 & $\mathbf{4 4 . 4 \%}$ \\
\hline
\end{tabular}

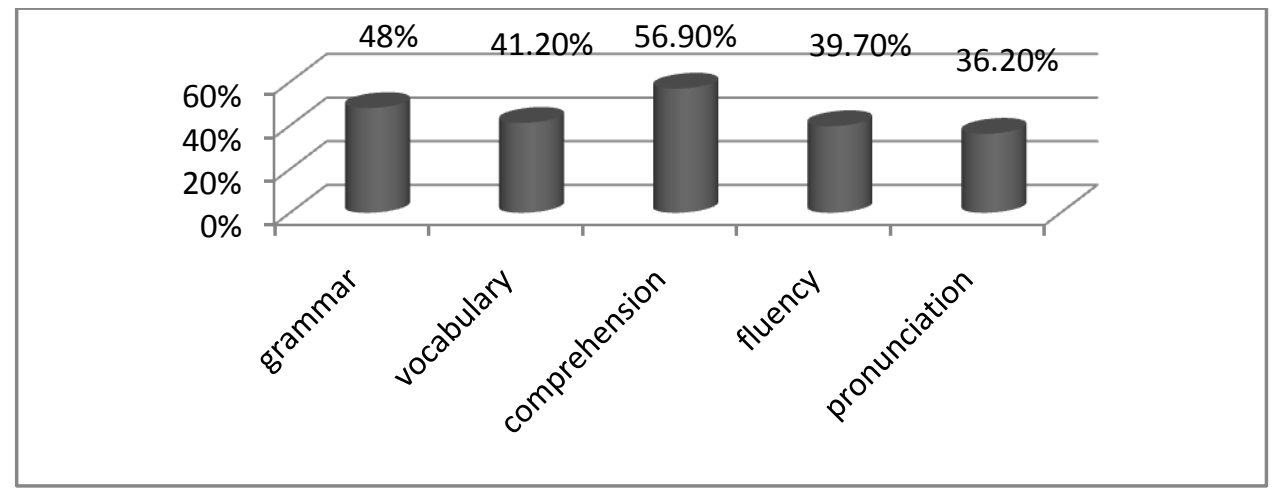

Fig. 3. Increased Polygon Test Results post-treatment

According to the table and polygon above it can be seen that comprehension indicator was the highest componen that increase with a value increase of $56,9 \%$. Next grammar indicator with increase value is $48 \%$. Value of vocabulary indicator 
increase was $41,20 \%$. Next to the indicators fluency value increase was $39,7 \%$ and the lowest increase is pronunciation indicator with value increase is $36.20 \%$. All indicators are improving and the overall improvement of the test results occurred at $44.4 \%$, after the treatment.

Accordance with the purpose of this research, the data analysis done by tests of significance to the application of the $\mathrm{t}$ test, then the acquisition of scores need to be sought. The following data on the acquisition score test table t-test. Data shows that by using t-test obtained $\mathrm{t}$ - score is $-140962,000$ while $\mathrm{t}$-table is 2,000 with significant level is $95 \%(\alpha=0.05)$, thus it can be concluded that the model of development of Socio-affective strategies have a significant impact on the students' speaking ability (speaking I). The table as below:

Table 4. Significance Test Result

\begin{tabular}{|c|c|c|c|c|}
\hline Test & Mean & t-score & t- table & Result \\
\hline Pre-test & 14,6750 & 11,814 & 2,0809 & Significant \\
\hline Post-test & 19,8711 & & \\
\hline
\end{tabular}

The table above indicate that the results of the analysis of product trials that have been done have a positive impact on speaking skill, in this case is Speaking II subject. Data shows that at the initial assessment average value is 14.6750 and the average score of the final test increased to 19.8711. In other words, t-count (11.814) is bigger than t-table (2.0809) . It can be concluded that the development of SCAS model gave the significant impact on students' speaking skills or a positive impact on learning outcomes in Speaking II.

\section{CONCLUSION}

The conclusion of this research is that the experiment of developing the module about heroes' live biography by using SCAS Model for teaching speaking in IAIN Bukittinggi is affective. The result of the score from pre-test and post- test has increased 44.4\%. The speaking material about heroes' live biography has given significant affect and good impact on the students. In other words, the researcher believes that through the speaking materials by insertingg SCAS model can helpthe lecturer to arouse their students' patriotism and cope of the effects of globalization. The most important thing is the module of speaking materials have a purpose to make characters buildings in the students life.

\section{References}

Bao, D.(2003). Materials for Developing Speaking Skills. In B.Tomlinson (ed), Developing Materials for Language Teaching. UK: Continuum.. Brumfit (ed.) General English Syllabus Design. Curriculum and Syllabus Design forr the General English Classroom. ELT Documents 118. Oxford : Pergamon Press and the British Council

Breen, M.P. (1984). 'Process Syllabus for the Language Classroom'. In G.J

Brown, J.D. (2011). Quantitative Research in Second Language Studies. In: E. Hinkel (Ed.), Handbook of Research in Second Language Teaching and Learning, Volume 2, New York: Routledge, pp 190-206

Englebert (2004) Character or Culture? An EFL Journal, 24(2), 37-41. Hantrais L (1989) The undergraduate's guide to studying languages. London: Centre for Information on Language Teaching and Research.

Nunan, David (1989). Task-Based Language Teaching . Oxford: Cambridge University Press

Tomlinson, Brian (1989). Materials Development inn Language Teaching. Oxford : Cambridge University Press 